\title{
POLA PEMASARAN SAPI POTONG JENIS PERANAKAN ONGOLE DI PASAR BLANTIK KAWANGKOAN (STUDI KASUS)
}

\author{
Jurian Weydekamp, T. D. F. Lumy, E. K. M. Endoh", F. N. S. Oroh \\ Fakultas Peternakan Universitas Sam Ratulangi Manado 95115
}

\begin{abstract}
ABSTRAK
Kajian ini bertujuan untuk mengidentifikasi pola pemasaran sapi potong dan penyebab terjadinya perbedaan harga sapi potong di pasar blantik kawangkoan. Sampel ditentukan dengan teknik purposive sampling maka ditetapkan sampel (responden) berjumlah 10 orang.

Kriteria penentuan sampel adalah: 1). Memiliki pengetahuan tentang kegiatan pemasaran di pasar blantik. 2). Aktif dalam setiap kegiatan pemasaran. 3). Berpengalaman dalam transaksi sapi potong di pasar blantik. Metode pengumpulan data yang digunakan adalah survei dan wawancara. Analisis data secara deskriptif dengan mengkaji kejadian di lapangan dan hasil-hasil penelitian sebelumnya.

Penilaian eksterior merupakan faktor yang sangat mempengaruhi perbedaan harga sapi potong di pasar blantik kawangkoan.
\end{abstract}

Kata Kunci : Pola pemasaran, pasar "blantik", sapi potong.

*Korespondensi (corresponding author): E-mail; eusebiusendoh@unsrat.ac.id

\section{ABSTRACT}

MARKETING PATTERN OF ONGOLE CROSSBRED BEEF CATTLE IN THE KAWANGKOAN "BLANTIK" MARKET (CASE STUDY). This study was done to identify the marketing pattern of beef cattle and factors causing the price difference at kawangkoan "blantik" market. The sample was determined using method of purposive sampling techniques and involving respondent of 10 household farmers. The criteria of respondents were as follows: 1). They had knowledge of "blantik" market marketing activities. 2). They were active in any marketing activity 3 ). They had the experiences in the transaction of beef cattle in the "blantik" market place. Data collections method used were conducted by surveys and interviews. A sort of descriptive set data analysis was examined the cases occurred in the field and the results of previous studies.

The exterior assessment was factor mostly affecting different prices in the "blantik" market of Kawangkoan.

Key word : Marketing pattern, "blantik" market, beef cattle. 


\section{PENDAHULUAN}

Usaha peternakan mempunyai prospek untuk dikembangkan karena tingginya permintaan akan produk peternakan. Tingginya permintaan pasar pada produk peternakan memberikan keuntungan dan menjadi sumber pendapatan. Sapi potong merupakan komoditas sub sektor peternakan yang sangat potensial, hal ini dapat dilihat dari tingginya permintaan akan produk daging sapi di pasaran (Rianto dan Purbowati 2010). Dari aspek konsumsi berdasarkan budaya dan rasa, posisi ternak sapi tidak dapat tergantikan, ketersediaan daging sapi selalu dibutuhkan semua kalangan masyarakat (Ilham 2009).

Ditinjau dari sisi potensi yang ada, Indonesia selayaknya mampu memenuhi kebutuhan pangan asal ternak dan berpotensi menjadi pengekspor produk peternakan. Hal tersebut dimungkinkan karena didukung oleh ketersediaan sumber daya alam yang berlimpah, sumber daya manusia, serta ketersediaan inovasi teknologi. Provinsi Sulawesi Utara merupakan salah satu daerah produksi/konsumsi produk peternakan, memiliki potensi yang besar dalam pengembangan usaha peternakan khususnya usaha pengembangan ternak sapi karena didukung oleh sumber daya alam seperti lahan, pakan, sumber daya manusia, dan peluang pasar yang memadai (Elly et al., 2008).
Untuk memasarkan sapi potong kepada konsumen pemilihan saluran pemasaran merupakan suatu hal yang penting dalam setiap kegiatan pemasaran, keterlibatan lembaga-lembaga pemasaran merupakan salah satu penyebab terbentuknya sebuah saluran pemasaran oleh sebab itu pemilihan saluran pemasaran harus diperhatikan karena akan berdampak kepada konsumen akhir.

Pasar "blantik" kawangkoan merupakan salah satu tempat untuk memasarkan sapi potong di daerah kabupaten minahasa dan sekitarnya, berdasarkan pengamatan di lapangan ditemukan keunikan pada pola pemasaran sapi potong. Pola pemasaran disetiap daerah memiliki karakteristiknya masing-masing, di beberapa daerah proses pemasaran sapi potong sangat rumit dan kompleks serta masih bersifat tradisional dan dihadapkan dengan beberapa masalah diantaranya harga produk, kualitas produk yang akan diterima konsumen, dan keuntungan yang tidak merata. Di daerah Aceh karakteristik pemasaran sapi potong memiliki perbedaan dengan daerah lainnya dimana posisi jaggal yang merupakan lembaga pemasaran terintegrasi dengan pedagang daging dengan kata lain pedagang daging merupakan kelompok lembaga-lembaga pemasaran (Yusuf dan Nulik. 2008). Pola pemasaran sapi potong yang terjadi memberikan dampak pada kegiatan pemasaran yang ada 
di pasar seperti harga sapi potong yang berbeda pada proses transaksi ternak sapi potong jenis peranakan ongole di pasar "blantik" kawangkoan.

Berdasarkan latar belakang dapat dirumuskan masalah sebagai berikut ; Pola pemasaran seperti apa yang terjadi dalam kegiatan pemasaran sapi potong, dan apa saja yang menyebabkan terjadinya perbedaan harga jual-beli sapi potong jenis peranakan ongole di pasar "blantik" kawangkoan. Tujuan penelitian adalah untuk mengidentifikasi pola pemasaran dan penyebab terjadinya perbedaan harga sapi potong jenis peranakan ongole di pasar blante kawangkoan.Penelitian ini dapat membantu memberikan tambahan pengetahuan dan informasi tentang pemasaran ternak sapi potong di Pasar "blantik" Kawangkoan Kabupaten Minahasa Provinsi Sulawesi Utara.

\section{METODE DAN MATERI PENELITIAN}

Penelitian telah dilaksanakan pada bulan November 2018 s/d bulan Januari 2019. Lokasi penelitian bertempat di Pasar "blantik" Kawangkoan. Kajian ini merupakan studi kasus. Studi kasus bermanfaat untuk memberikan informasi pada penelitian selanjutnya, karena dapat memberikan penjelasan tentang variabelvariabel penting.

Sampel ditentukan dengan teknik Purposive Sampling (non-probabilitas sampling) dimana sampel dipilih dengan menetapkan ciri-ciri khusus yang sesuai dengan tujuan penelitian sehingga diharapkan dapat menjawab permasalahan penelitian, maka ditetapkan sampel yang disebut sebagai responden kunci adalah Mandor Pasar "blantik" (Ibu. Linda Supit), Kepala Pasar Tradisional Kawangkoan (Bpk. Ferry Rintjap), Petani/Peternak Sapi potong (Bpk. Hanz, Bpk. Ardiles) Pedagang (Bpk. Arjuna, Bpk. Ayub, Bpk. Tomi) Perantara (Bpk. Evert, Bpk. Otep, Bpk. Windy). Responden dipilih berdasarkan kriteria sebagai berikut ; 1). Memiliki pengetahuan tentang kegiatan pemasaran di pasar "blantik". 2). Aktif dalam setiap kegiatan pemasaran. 3). Berpengalaman dalam transaksi sapi potong di pasar "blantik". Metode pengumpulan data yang digunakan adalah metode survei dan wawancara. Data terdiri dari data primer, adalah data yang diperoleh langsung dari responden dengan cara wawancara, dan data sekunder yang diperoleh dari studi pustaka dan dari instansi-instansi terkait yang berhubungan dengan masalah yang diteliti.

Peneliti menggunakan pendekatan kualitatif dengan analisis data secara deskriptif dengan mengkaji kejadian di lapangan dan hasil-hasil penelitian sebelumnya, penelitian kualitatif yaitu jenis penelitian yang digunakan untuk meneliti kondisi objek alamiah dimana yang menjadi instrument kunci adalah pihak peneliti 
(Sugiyono. 2012), Variabel yang diteliti dalam penelitian ini adalah pola pemasaran sapi potong dan penyebab perbedaan harga sapi potong jenis peranakan ongole di pasar "blantik" kawangkoan.

\section{HASIL DAN PEMBAHASAN}

\section{Pasar "blantik" Kawangkoan}

Pasar "blantik" kawangkoan merupakan pasar hewan tempat khusus untuk memasarkan sapi potong dan merupakan bagian dari pasar tradisional kawangkoan yang sudah ada sejak tahun 1960-an. Kegiatan pemasaran sapi potong seperti jual beli dan tukar tambah (barter) ternak sapi di pasar "blantik" kawangkoan dilakukan setiap hari kamis dimulai pukul 08.00 s/d 16.00 WITA. Para pelaku pasar yang terlibat dalam kegiatan pemasaran di pasar "blantik" merupakan masyarakat yang berasal dari daerah Kabupaten Minahasa, Kabupaten Bolaang Mongondow, Kota Tomohon, Kota Bitung, hingga Gorontalo dan sekitarnya. Pasar memiliki sarana prasarana dan luas area yang memadai untuk pemasaran sapi potong dan juga memiliki petugas pasar (Mandor) yang bertanggung jawab terhadap seluruh proses transaksi yang terjadi selama kegiatan pemasaran berlangsung.

Dilihat dari strukturnya, seluruh kegiatan pemasaran yang terjadi di pasar "blantik" kawangkoan termasuk dalam model pasar persaingan monopolistik. Pasar persaingan monopolistik adalah suatu pasar dimana terdapat banyak produsen yang menjual atau menghasilkan barang yang serupa tetapi tidak persis sama ada juga yang menjual produk yang sama pada tingkat harga yang berbeda. Pasar persaingan monopolistik memiliki ciri-ciri sebagai berikut : 1) Terdapat banyak penjual, 2). Barang yang dijual sejenis namun berbeda corak, 3). Para pedagang atau perusahaan mempunyai sedikit kekuasaan mempengaruhi harga, 4). Kebebasan untuk keluar dan masuk kedalam pasar, 5). Persaingan promosi penjualan sangat mudah (Sumarsono. 2007).

Ciri-ciri yang nampak di pasar "blantik" kawangkoan sangat mencerminkan model pasar persaingan monopolistik dimana terdapat banyak penjual yang menjual produk yang sama yaitu sapi potong namun berbeda corak atau memiliki perbedaan antara satu dengan laninnya, para peternak maupun masyarakat juga bebas melakukan transaksi baik itu menjual maupun membeli sapi dengan kemudahan untuk melakukan promosi di area pasar.

\section{Pola Pemasaran Sapi Potong di Pasar "Blantik"Kawangkoan}

Secara sederhana pola pemasaran sapi potong dapat didefinisikan sebagai bentuk atau model cara memasarkan hasil dari proses produksi peternakan sapi potong. Pada pola pemasaran sapi potong terdapat 
saluran-saluran pemasaran yang di dalamnya terdiri dari lembaga pemasaran.

Adanya perantara dalam proses penjualan sapi di pasar "blantik" disebabkan karena terjadinya Asymetri Information dalam hal ini pihak perantara memiliki informasi dan pengetahuan yang lebih tentang pasar dari pada para petani/peternak dan pedagang (Elly. 2009). Pola pemasaran secara tidak langsung terjadi antara peternakpemilik sapi dan konsumen karena proses pemasaran sapi melalui perantara di area pasar. Pedagang yang dimaksud terlibat dalam kegiatan pemasaran adalah pedagang pengumpul, pedagang daging, dan pedagang antar daerah, yang bertindak sebagai perantara dalam kegiatan pemasaranadalah "blantik" orang yang menjadi penghubung antara petani-peternak atau pemilik sapi dan pedagang sapi.

Menurut Suwandi blantik adalah pedagang perantara yang wilayah kerjanya meliputi tingkat desa sampai lintas kabupaten (Suwandi, 2005; Elly, 2009). Berdasarkan hasil suvei di lapangan jumlah pelaku pasar yang ada setiap harinya \pm 100 s/d 150 orang dan untuk ternak sapi yang dipasarkan berjumlah rata-rata 200 ekor ternak (jumlah yang dimaksud bukan ratarata ternak yang terjual)

\section{Proses Pemasaran Sapi Potong di Pasar "Blantik" Kawangkoan}

Proses pemasaran secara umum yang dilakukan untuk memasarkan sapi potong setiap hari kamis di pasar "blantik" kawangkoan. Mereka membawa sapi yang akan dipasarkan menggunakan kendaraan roda empat (mobil Pick-up) dan ada juga yang membawa sapi ke pasar hanya dengan berjalan kaki atau menggunakan roda sapi (kendaraan tradisional yang digerakan menggunakan tenaga sapi dan biasanya digunakan masyarakat Minahasa sebagai alat transportasi).

Penentuan harga sapi dilakukan dengan cara tawar-menawar secara langsung dengan memperhatikan keadaan serta kualitas sapi dan untuk mengukur berat hanya berdasarkan perkiraan atau taksiran (berat taksir) ini tidak merugikan pihak manapun karena proses transaksi dilakukan secara langsung dan disetujui oleh pihak penjual maupun pembeli. Seperti yang terjadi pada proses pemasaran sapi di pulau Madura sistem jual/beli sapi potong dilakukan dengan sistem taksasi atau taksiran, penentuan harga hanya dengan melihat penampilan dari sapi potong tidak berdasarkan dengan berat badan sapi. Penampilan sapi yang "gantheng" harganya akan lebih mahal (Heryadi. 2011).

Proses pemasaran sapi potong yang dilakukan di pasar blante kawangkoan adalah sebagai berikut:

1. Proses Drop-Off 
Sapi potong yang akan dijual dibawa ke pasar mulai pukul 08.00 WITA menggunakan kendaraan. Proses drop-off sapi dilakukan secara manual oleh para pelaku pasar dengan menggunakan sarana/prasarana yang ada.

2. Proses Tawar-menawar

Para pelaku pasar berusaha menarik perhatian pembeli dengan menunjukan keadaan sapi yang akan dijual.sebelum dijual ternak sapi diperagakan oleh perantara (Elly 2009), untuk mendapatkan perhatian dan kepuasan konsumen setiap perantara atau pedagang harus memperhatikan strategi pemasaran (Ishak 2005). Setelah berhasil mendapatkan perhatian pembeli proses tawar menawar harga sapi dilakukan dengan memperhatikan keadaan sapi.

3. Proses pembayaran

Jika proses tawar menawar sudah disepakati, proses pembayaran ternak sapi langsung dilakukan ditempat dengan bantuan petugas pasar (Mandor) untuk keperluan regulasi dan lain-lain.

Setelah transaksi sukses dilakukan ternak sapi sudah langsung bisa dibawa pulang, namun beberapa dari para pelaku pasar menjual kembali ternak sapi hasil transaksi sebelumnya. Hal ini biasa dilakukan dengan tujuan untuk mendapatkan keuntungan.

\section{Perbedaan Harga Sapi Potong di Pasar"Blantik"Kawangkoan}

Campur tangan para perantara dalam proses pemasaran memberikan dampak pada harga sapi di pasar. Berdasarkan hasil survei dan wawancara dengan para responden di pasar "blantik" kawangkoan, perbedaan harga sapi potong terbukti benar terjadi. responden (Mandor Pasar) menyatakan bahwa memang benar terjadi perbedaan harga dalam kegiatan pemasaran sapi, perbedaan harga sudah menjadi hal yang wajar bagi para pelaku pasar "blantik" kawangkoan, hal ini sudah menjadi kebiasaan dan juga peluang para pelaku pasar untuk mendapatkan keuntungan. Menurut keterangan salah responden yang menyatakan bahwa sejak pertama kali memasarkan sapi pada tahun 1965 perbedaan harga sapi sudah terjadi, kejadian ini sudah ada sejak lama. Responden (Kepala Pasar Tradisional Kawangkoan) menyatakan, perbedaan harga yang terjadi disebabkan oleh beberapa faktor dikarenakan ternak sapi yang dijual di pasar memiliki perbedaan.

\section{Penyebab Terjadinya Perbedaan Harga}

Berikut ini adalah penyebab terjadinya perbedaan harga sapi potong jenis peranakan ongole di pasar blantek kawangkoan disebabkan berdasarkan variasi

\section{Penilaian Eksterior Sapi (Tanda- tanda sapi).}

Penilaian Eksterior atau tanda-tanda sapi seperti postur, warna, dan pusir rambut 
memberikan pengaruh yang sangat besar terhadap perbedaan harga sapi di pasar "blantik" kawangkoan. Sapi yang memiliki tanda-tanda yang lengkap dikategorikan sebagai sapi class/unggul (sebutan para pelaku pasar). Postur tubuh sapi yang mempengaruhi harga adalah sapi berperawakan "pasung”. Menurut Elly (2009) kategori sapi di pasar terbagi menjadi kualitas nomor 1 dan nomor 2. ciri-ciri ternak sapi dengan kualitas nomor 1 adalah berwarna putih bersih, kulitnya licin, mempunyai tanda di dahi dan ekornya kecil, bentuk tubuh simetris.

Warna bulu/rambut sapi yang ada dipasar "blantik" yang memberikan pengaruh terhadap harga adalah sapi dengan warna bulu/rambut putih cerah, warna rossi agak kecokelatan dan triko warna putih dengan corak hitam dari kepala sampai punggung (sebutan para pelaku pasar) dari ketiga warna sapi yang ada di pasar, warna putih cerah memiliki harga yang lebih mahal. Pusir/pulis rambut menjadi perhatian para peternak/pedagang blantik dalam menentukan harga, bisa dilihat pada gambar 2, letak dan jumlah pusir rambut yang diperhatikan adalah sebagai berikut : 1.) 4 dibagian kepala - 1 terdapat di kepala bagian depan, dan 3 terdapat di kepala bagian belakang dekat dengan tanduk.; 2.) 1 dibagian punggung sapi. pusir rambut pada sapi jantan dan betina tidak memiliki perbedaan.

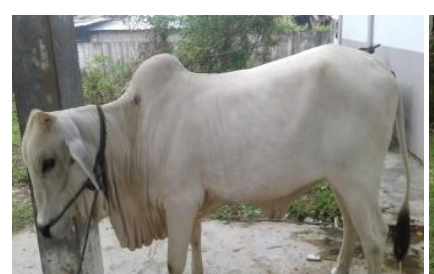

Putih

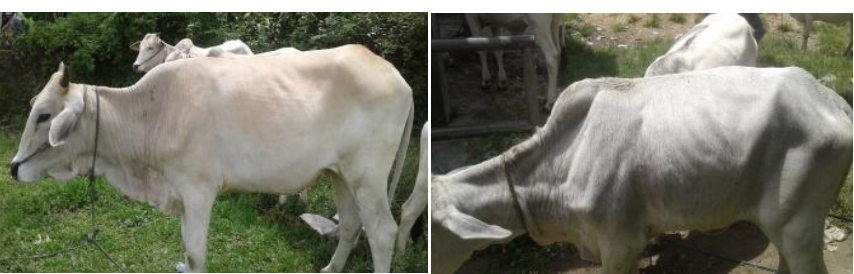

Triko

Gambar 1. Warna Sapi Di Pasar "Blantik" Kawangkoan

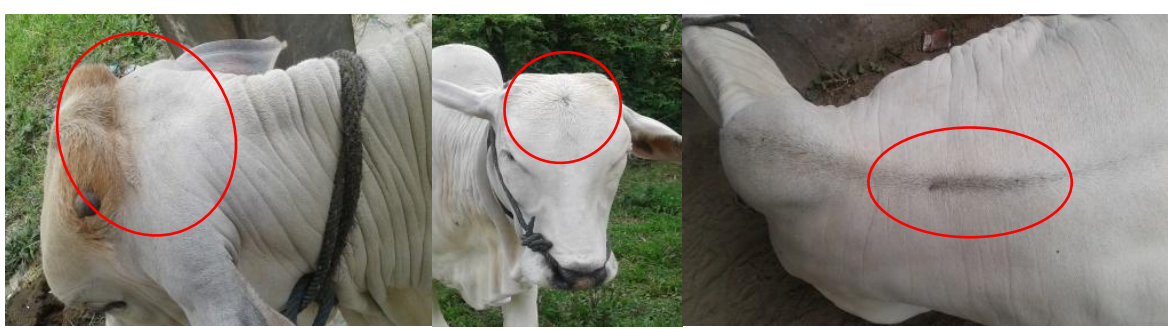

Gambar 2. Letak Pusir/Pulis Rambut 


\section{Penilaian Fisik Sapi}

Penilaian fisik sapi seperti jenis, umur, berat badan, dan tingkah laku sapi merupakan penilaian yang dilakukan masing-masing para pelaku pasar dan dapat mempengaruhi harga sapi. untuk jenis sapi yang dipasarkan di pasar blante kawangkoan mayoritas berjenis sapi PO. Umur sapi yang dipasarkan beragam sesuai dengan tujuan penggunaan sapi atau tujuan sapi itu dijual. Peneliti mengkategorikan umur sapi menjadi dua, yaitu ; umur 1 s/d 3 tahun untuk kategori sapi remaja dan umur $>3$ tahun untuk kategori sapi dewasa berdasarkan informasi dari para responden. Berat badan berpengaruh terhadap harga sapi yang khusus untuk dipotong namun untuk sapi yang akan dijadikan bibit atau untuk dipelihara pengaruhnya relatif. Tingkah laku sapi berdasarkan budaya atau kebiasaan dari masing-masing peternak/pedagang blantikadalah menilai dan memperhatikan

cara jalan dan respon sapi (kelincahan sapi), hal tersebut memiliki nilai tersendiri menurut masing-masing pelaku pasar dan dapat mempengaruhi harga.

\section{Maksud dan Tujuan Penggunaan}

Maksud dan tujuan penggunaan adalah sebagai berikut : 1.) Dipotong.; 2.) Dipelihara. Berdasarkan maksud dan tujuan penggunaan, sapi untuk dipotong biasanya sapi yang tidak masuk dalam kriteria sapi kelas dan memiliki harga yang berbeda dengan sapi kelas untuk dipelihara. Ratarata harga sapi kelas remaja berkisar dari Rp. 8.000.000 s/d Rp. 15.000.000. untuk sapi kelas dewasa berkisar dari Rp. 20.000.000 s/d \pm Rp. 50.000 .000 hitungan harga rata-rata sapi berdasarkan data yang diberikan oleh para responden. Responden menyatakan harga antara sapi berbeda sesuai dengan tujuan penggunaan sapi. Peneliti menemukan perbedaan harga sapi berfluktuasi disebabkan oleh keadaan dan kualitas dari sapi yang dipasarkan.

\section{Faktor-Faktor Lain yang Mempengaruhi}

1). Waktu penjualan sapi memiliki pengaruh terhadap perbedaan harga. Contohnya harga sapi akan berfluktuasi jika sudah mendekati hari-hari raya (lebaran, kurban, natal, tahun baru, dsb). 2). Keperluan ekonomi, umumnya akan mempengaruhi harga sapi menjadi lebih murah dikarenakan peternak atau pemilik sapi akan menjual sapi dengan harga dibawah rata-rata untuk memenuhi keperluan keluarga seperti untuk biaya sekolah, pernikahan, pengobatan, dan lain sebagainya. 3). Selera, mempengaruhi harga terhadap sapi yang akan dibeli berdasarkan keinginan mencari sapi dengan kriteria dari masing-masing pembeli dengan asumsi berapa pun harga sapi tersebut yang sesuai dengan selera akan dibeli. 


\section{KESIMPULAN}

Berdasarkan hasil dan pembahasan dapat disimpulkan bahwa pola pemasaran sapi potong di pasar "blantik" kawangkoan dilakukan secara langsung oleh pedagang dan perantara di area pasar. Banyak faktor yang mempengaruhi perbedaan harga sapi potong jenis peranakan ongole di pasar. Perbedaan harga disebabkan berdasarkan : 1). Penilaian Eksterior (Tanda-tanda sapi) menjadi faktor-faktor yang sangat mempengaruhi perbedaan harga. 2). Penilaian Fisik, 3). Maksud dan tujuan penggunaan, 4). Waktu penjualan, 5). Keperluan ekonomi, 6). Selera. Perbedaan harga sapi potong berfluktuasi disebabkan oleh keadaan dan kualitas sapi yang dijual.

\section{DAFTAR PUSTAKA}

Elly, F. et al., 2008. Pengembangan usaha ternak sapi rakyat melalui integrasi sapi-tanaman di Sulawesi Utara. Jurnal Litbang Pertanian, 27(2) : 6368.

Elly, F. 2009. Peranan pasar "blantik" dalam menunjang ternak sapi di Kabupaten Minahasa. Jurnal Zootek, $28: 92-103$.

Heryadi, A. Y. 2011. Pola pemasaran sapi potong di pulau madura. J-SEP. 5 (2) : $38-46$.

Ilham, N. 2009. Kebijakan pengendalian harga daging sapi nasional. Analisis Kebijakan Pertanian. 7 (3) : 211-221.
Ishak, A. 2005. Pentingnya kepuasan konsumen dan implementasi strategi pemasarannya. Jurnal Siasat Bisnis. 3(1) :1-11.

Rianto, E. dan E. Purbowati. 2010. Panduan Lengkap Sapi Potong. Penebar Swadaya. Jakarta.

Sugiyono. 2012. Memahami Penelitian Kualitatif. Alfabeta 39. Bandung.

Sumarsono. 2007. Ekonomi Mikro. Graha Ilmu. Edisi pertama. Yogyakarta.

Suwandi. 2005. Keberlanjutan Usaha Tani Terpadu Pola Padi Sawah-Sapi Potong Terpadu Di Kabupaten Sragen. Disertasi. Pascasarjana Institut Pertanian Bogor.

Yusuf, dan J. Nulik. 2008. Kelembagaan pemasaran ternak sapi potong di Timor Barat, Nusa Tenggara Timur. Jurnal Pengkajian dan Pengembangan Teknologi Pertanian 11 (2) : 133-145 